\title{
1 Space use and movement of jaguar (Panthera onca) in western Paraguay
}

2 Roy T McBride, Jr. ${ }^{\mathrm{a}, 1}$, Jeffrey J Thompson*b,c,1

$3 \quad{ }^{a}$ Faro Moro Eco Research, Departamento de Boquerón, Paraguay

$4 \quad{ }^{\mathrm{b}}$ Consejo Nacional de Ciencia y Tecnología (CONACYT), Asunción, Paraguay

5 'Asociación Guyra Paraguay, Parque Ecológico Asunción Verde. Avda. Carlos Bóveda,

6 Asunción, Paraguay C.C:132

7

$8 \quad{ }^{1}$ These authors contributed equally to this paper.

$9 \quad *$ Corresponding author: jthompson.py@gmail.com

10 Guyra Paraguay

11 Parque Ecológico Asunción Verde. Avda. Carlos Bóveda

12 Asunción, Paraguay C.C:132

13595975928079

14 jthompson.py@gmail.com

Faro Moro Eco Research

17 Departamento de Boquerón, Paraguay

18 rocktmcbride@yahoo.com

19

20 Running title: Jaguar home ranges in Paraguay 
Abstract: We estimated home range and core area size for jaguar (Panthera onca) in western

27 Paraguay in the Dry Chaco, Humid Chaco and Pantanal using an autocorrelated kernel density estimator. Mean home range size was $818 \mathrm{~km}^{2}$ (95\% CI:425-1981) in the Dry Chaco and 237 $\mathrm{km}^{2}$ (95\% CI:90-427) in the Humid Chaco/Pantanal. Core areas, defined as the home range area where use was equal to expected use, was consistent across sexes and systems represented on average by the $59 \%$ utility distribution isopleth (range:56-64\%). Males had a higher probability of larger home ranges and more directional and greater daily movements than females collectively and within systems. The large home ranges in the Dry Chaco are attributable to the relatively low productivity of that semi-arid ecosystem and high heterogeneity in resource distribution while larger than expected home ranges in the Humid Chaco/Pantanal compared to home range estimates from the Brazilian Pantanal may be due to differences in geomorphology and hydrological cycle. The large home ranges of jaguars in western Paraguay and a low proportional area of protected areas in the region demonstrate the importance of private ranchland for the long-term conservation of the species.

Keywords: Adaptive kernel density estimation; home range; jaguar; Panthera onca; Paraguay

44 Globally, apex predators, and the maintenance of their functional roles, are severely threatened 45 due to anthropogenic pressures, particularly associated with large spatial needs to access

46 sufficient prey to meet metabolic requirements and persecution (Ripple et al. 2014). Habitat

47 conversion and degradation and over hunting of prey species increase spatial requirements of 
48 apex predators, increasing conflict with humans and affecting social behavior, dispersal and

49 habitat use (McDonald 1983; Crooks 2002; Cardillo et al. 2004; Ripple et al. 2014).

50 Consequently, an understanding of the space use and movement ecology of apex predators is key

51 to effective conservation decision making for these species.

The jaguar (Panthera onca) is the largest feline in the Americas, distributed from the southwestern United States to northern Argentina, although it presently occupies $<50 \%$ of its

54 original range, and $<80 \%$ of the range outside of Amazonia, due to habitat loss and persecution

55 (Sanderson et al. 2002; Zellar 2007; de la Torre et al. 2017). Given the contraction of the

56 species' distribution, range-wide conservation efforts have focused upon maintaining

57 connectivity among key populations throughout the species range (Sanderson et al. 2002;

58 Rabinowitz and Zeller 2010), however, an effective implementation of this management

59 approach is partly dependent upon a thorough understanding of the spatial and movement ecology of jaguars.

For a big cat the jaguar is relatively understudied (Brodie 2009), and although multiple

62 studies have estimated jaguar home range size (Schaller and Crawshaw 1980; Rabinowitz and

63 Nottingham 1986; Crawshaw and Quigley 1991; Crawshaw 1995; Scognamillo et al. 2002;

64 Crawshaw et al. 2004; Silveira 2004; Cullen 2006; Azevedo and Murray 2007; Cavalcanti and

65 Gese 2009; Tobler et al. 2013; Morato et al. 2016) and movements (Conde et al. 2010; Colchero

66 et al. 2011; Sollman et al. 2011; Morato et al. 2016), there is still relatively little known about the

67 species' spatial and movement ecology. Since anthropogenic factors drive jaguar occurrence

68 throughout its range by determining habitat availability and quality (Zeller et al. 2012; Petracca

69 et al. 2014a,b; Thompson and Martinez 2015) this conspicuous knowledge gap on how jaguars 
70

71

72

73

74

75

76

77

78

79

80

81

82

83

84

85

86

87

0

perceive and use the landscape is of concern as it limits managers' ability to quantifiably design and manage conservation landscapes for the jaguar.

Of further concern is that until recently jaguar home range estimates likely underestimated space use as VHF-based estimates were based upon small number of locations, while GPS-based estimates failed to account for autocorrelation inherent in GPS telemetry data (Morato et al. 2016). Furthermore, only recently have movement parameters and quantitative assessment of home range residency been estimated for jaguar (Morato et al. 2016).

Consequently, there is an important need for research that incorporates developing methodologies that account for and take advantage of autocorrelation in telemetry data to better quantify jaguar spatial and movement ecology.

Range-wide, the jaguar is considered near threatened (Caso et al. 2008), however, at the austral limit of its distribution the species is considered critically endangered in Argentina and endangered in Brazil and Paraguay. Although multiple studies have investigated space use by jaguar in Brazil and Argentina (Schaller and Crawshaw 1980; Crawshaw and Quigley 1991; Crawshaw 1995; Crawshaw et al. 2004; Silveira 2004; Cullen 2006; Azevedo and Murray 2007; Cavalcanti and Gese 2009; Morato et al. 2016) there has been no such research on the species in Paraguay despite a recognized need in the face of a rapid constriction in the species' distribution in relation to a country-wide expansion of the agricultural sector (Secretaría del Ambiente et al. 2016) which has resulted in some of the highest rates of deforestation in the world (Hansen et al. 2013).

Given the status of the jaguar in Paraguay, the lack of information on the spatial and movement ecology of the species is of concern within the context of continued habitat loss, the maintenance of in-country and trans-boundary connectivity of populations, and their implications 
93 for the range-wide conservation of the jaguar. Consequently, we used GPS-based telemetry to

94 study space use and movements of jaguars in western Paraguay in the Dry Chaco, Humid Chaco

95 and Pantanal, the region with the largest jaguar population in the country. Moreover, we

96 employed developing methodologies which allowed us to determine home range residency and

97 account for autocorrelation in the data (Fleming et al. 2014, 2015; Calabrese et al. 2016), which

98 in turn allowed for rigorous comparisons with estimates from other research employing the same

99 methodologies (Morato et al. 2016).

Based upon carnivore ecology in general, and jaguar ecology specifically, we expected

101 male home range and movement rates to be higher than females (Mikael 1989; Cavalcanti and

102 Geese 2009; Conde et al. 2010; Sollmann et al. 2011; Morato et al. 2016) and that jaguars in the

103 Dry Chaco would exhibit larger home ranges, higher movement rates, and more directional

104 movement compared to those in the more productive habitats of the Humid Chaco and Pantanal

105 (Mikael 1989; Fahrig 2007; Gutierrez-Gonzalez et al. 2012). Also, when comparing to other sites

106 (Morato et al. 2016) we expected estimated from the Humid Chaco and Pantanal to be similar to

107 those from the Brazilian Pantanal, while estimates from the Dry Chaco would be larger than

108 those from more humid systems but possibly similar to jaguars from the Brazilian Cerrado due to

109 biotic and abiotic similarities between systems. Apart from constituting an important

110 contribution towards the conservation of jaguars within Paraguay, placing our results into a

111 comparative context with research from neighboring countries will facilitate the efficacy of

112 trans-boundary conservation efforts, with important implications for range-wide conservation

113 strategies for jaguar. 


\section{Study area}

117 We conducted our study in three ecosystems in western Paraguay; Dry Chaco, Humid Chaco and

118 Pantanal, (Figure 1). The Dry Chaco is comprised of xeric forest, savannas, and grasslands and

119 the Humid Chaco and Pantanal are a mosaic of seasonally flooded grasslands, palm savanna and 120 xerophilic woodlands on higher ground (Olson et al. 2001; Mereles et al. 2013). We note that

121 delineations between the Humid Chaco and Pantanal differ (Olson et al. 2001; Mereles et al.

122 2013), however, for our purposes the similarities between systems and among our study sites in

123 those systems make this discrepancy moot and consequently we treat the Humid Chaco and

124 Pantanal as a single system in our analysis.

The western half of Paraguay is generally semi-arid with a pronounced east-west

126 gradient in precipitation and humidity which divides the Chaco into the Humid Chaco with

127 precipitation approximately $>1000$ mmlyear and the Dry Chaco with precipitation $<1000$

128 mmlyear (Olson et al. 2001). The Pantanal is also subjected to this east-west precipitation

129 gradient; however, it and the Humid Chaco are also strongly effect by the hydrological cycles of

130 the Rio Paraguay (Mereles et al. 2013).

In the Humid Chaco our study area was Estancia Aurora, a 30,000 ha cattle ranch in the

132 north of the department of Villa Hayes and in the Pantanal on the 65,000 ha ranch Estancia

133 Fortín Patria and on the 80,000 ha ranch Estancia Leda. In the central Dry Chaco, we worked on

134 the 40,000 ha Faro Moro ranch and more northerly in the 7,200 $\mathrm{km}^{2}$ Defensores del Chaco

135 National Park and the neighboring 269,000 ha of ranchland of the consortium Grupo Chovoreca.

\section{Jaguar captures}

137 Jaguars were captured using trained hounds to tree or bay jaguars which were then anesthetized 138 using a weight-dependent dose of a mix of ketamine hydrochloride and xylazine hydrochloride 
139 injected by a dart shot from a tranquilizer gun (McBride and McBride 2007). Capture methods

140 followed ASM protocols (Sikes 2016) and in > 60 captures and recaptures of jaguar and puma

141 over the study period there were no deaths or noticeable injury to animals.

From 2002-2009 jaguars were fitted with Telonics Generation II, data stored-on-board,

143 GPS collars (Telonics, Mesa, Arizona, USA) which were set to record locations at 4 hour

144 intervals. Starting in 2009 we used Northstar GPS collars (D-cell, Northstar, King George,

145 Virginia, USA) programmed to record locations at three or four hour intervals and in 2012 we

146 switched to Telonics Generation III GPS collars (Telonics, Mesa, Arizona, USA) which were set

147 to record locations daily every two hours from 1800 to 0600 hours.

\section{Home range estimation}

149 Semi-variogram analysis, model selection and AKDE estimates were undertaken using the ctmm

150 package (Calabrese et al. 2016) in R 3.3.2 (R Development Core Team 2010). Starting values

151 derived from semi-variograms were used for maximum likelihood model fitting with model

152 selection based upon Akaike Information Criteria, adjusted for small sample size (AICc), and

153 model weights (Fleming et al. 2014, 2015; Calabrese et al. 2016). We accounted for data

154 collected with an irregular sampling schedule from collars used starting in 2012 with the $d t$

155 argument within the variogram function in the ctmm package (Calabrese et al. 2016).

157 ignores autocorrelation in the data and is equivalent to kernel density estimation (KDE) (Worton

158 et al. 1989), a random search model (Brownian motion) with no home range, Brownian motion

159 within a home range (Ornstein-Uhlenbeck, OU), and Ornstein-Uhlenbeck motion with foraging

160 (OUF) (Fleming et al. 2014; Calabrese et al. 2016). Both the OU and OUF models produce 
161

162

163

estimates of home range size and home range crossing time, while the OUF model additionally estimates the velocity autocorrelation time scale (a measure of path sinuosity) and mean distance traveled (Fleming et al. 2014; Calabrese et al. 2016).

Home ranges were estimated using the best fit model for each individual using AKDE (Fleming et al. 2015; Calabrese et al. 2016). For comparison with home range estimates from previous research we estimated 95\% KDE home ranges using the IID model and 95\% Minimum Convex Polygons (MCP) home ranges using the adehabitatHR package in $\mathrm{R}$ (Calenge 2006) (Supplementary material Appendix 1).

\section{Core area estimation}

We estimated core areas of AKDE home ranges as the area encompassed within the isopleth where the proportional use of the estimated home range is equal to the predicted probability of use (Seaman and Powell 1990; Bingham and Noon 1997; Vander Wal and Rodgers 2012). We determined this by fitting an exponential curve to the isopleths of the utility distribution of each individual at $10 \%$ increments from $10 \%$ to $90 \%$, and at the $95 \%$ and $99 \%$ isopleths of the AKDE home range and the proportional area of the home range that each of those isopleths encompassed based upon the area of the $99 \%$ home range estimate. We then determined the threshold where proportional home range size begins to increase at a rate greater than the probability of use (slope=1; Seaman and Powell 1990; Bingham and Noon 1997; Vander Wal and Rodgers 2012) to define the isopleth that represented the core area boundary.

\section{Statistical analyses}

For our statistical analysis we combined jaguars from the Humid Chaco and the Pantanal into a single group as the characteristics of the system are highly similar, the delineation between the 
two systems is debatable (Olson et al. 2001; Mereles et al. 2013), and consequently jaguars from

184

185

186

187

188

189

190

191

192

193

194

195

196

197

198

199

200

201

202

203

204

those systems are subjected to similar ecological and anthropogenic drivers. Additionally, only

individuals that exhibited residency in their movement behavior through semi-variogram analysis

and space use best explained by the OUF model were included in our comparative analysis of

differences between sexes and ecosystems.

We used a fixed-effect one-way analysis of variance (ANOVA) in a Bayesian modeling framework to test for differences in estimates of home range size, home range crossing time, directionality in movement (velocity autocorrelation time scale) and mean daily distance traveled between sexes across systems, between systems (sexes combined), between sexes within a system, and between same sexes between systems. We tested normality using the Shapiro-Wilk test and log-transforming the data when its distribution did not meet assumptions of normality.

All analyses were undertaken in R 3.2.2. (R Development Core Team 2010) using WinBUGS (Lunn et al. 2000) and the R2bugs package (Sturtz et al. 2005) for the Bayesian analysis. We ran 3 chains in WinBUGS with 100,000 iterations and a 20,000 iteration burn-in period; confirming convergence by a scale reduction factor $\leq 1.01$ and visual inspection of trace plots for lack of autocorrelation. We tested differences between groups by taking 10,000 random samples from posterior distributions for each group of interest, comparing the proportional frequency that posterior estimates parameters were greater for males than females overall and within systems, greater for all individuals, and between same sexes, in the Dry Chaco compared to the Humid Chaco/Pantanal.

\section{Results}




\section{Jaguar captures and data collection}

206 We captured and collared 35 jaguars from June 2002 to June 2014 of which 19 individuals

207 provided sufficient data for analysis; 7 in the Dry Chaco (5 males, 2 females), 9 in the Humid

208 Chaco (3 males, 6 females) and 3 in the Pantanal (1 male, 2 females) with estimated ages

209 between 2 and 10 years (Table 1). Collars collected data between 52 and 439 days, obtaining

210 from 148 to 3462 locations (Table 1). The length of the study period and the annual frequency of

211 captures were dependent upon resource availability and logistical restraints that dictated captures

212 and collar recovery.

\section{Home range, core area and movement parameter estimates.}

214 Best fitting models for the movement of jaguars were either the OU or OUF models with 16

215 individuals demonstrating residency (Table 1). Estimated home range sizes varied between 86

216 and 2,909 $\mathrm{km}^{2}$ and core areas between $21-509 \mathrm{~km}^{2}$. Core areas were represented by a consistent

217 proportion of the utility distribution; ranging between $56 \%-64 \%$ isopleths (Table 2 ).

Male and female mean home range size were $727 \mathrm{~km}^{2}$ (95\% CI:355-1954) and $255 \mathrm{~km}^{2}$

219 (95\% CI:90-578), respectively and $818 \mathrm{~km}^{2}$ (95\% CI:425-1981) and $237 \mathrm{~km}^{2}$ (95\% CI:90-427)

220 for jaguars in the Dry Chaco and Humid Chaco/Pantanal, respectively (Fig. 2, Fig.3). In the Dry

221 Chaco mean home range size for males was $925 \mathrm{~km}^{2}(95 \% \mathrm{CI}: 424-2035)$ and $551 \mathrm{~km}^{2}(95 \%$

222 CI:513-590) for females, while in the Humid Chaco/Pantanal the mean home range was $398 \mathrm{~km}^{2}$

223 (95\% CI:345-427) and $156 \mathrm{~km}^{2}$ (95\% CI:90-267) for males and females, respectively (Fig. 4).

Males demonstrated larger home ranges $(P=0.99)$, higher daily movement $(P=0.84)$,

225 greater directionality in movement (velocity autocorrelation time scale) $(P=0.84)$ and lower

226 home range crossing times $(P=0.9)$ (Table 2, Figure 2). Between systems, home ranges were 
227 larger $(P=1)$, movements more directional $(P=0.99)$ and home range crossing times greater

$228(P=0.77)$ in the Dry Chaco, while daily travel distance was similar between systems but with a

229 slightly higher probability of being larger in the Dry Chaco $(P=0.61$, Figure 3$)$.

Between systems males in the Dry Chaco had higher probabilities to have larger home ranges $(P=0.91)$, higher home range crossing time $(P=0.75)$, greater directionality in movement

234 evident between females in both systems for home range size $(P=0.99)$, home range crossing time $(P=0.89)$ and directionality in movement $(P=0.96)$ which were greater for females in the Dry Chaco, however, females in the Dry Chaco had lower daily movements $(P=0.23)$ than those in the Humid Chaco/Pantanal (Table 4).

\section{Discussion}

We present the first estimates of movement parameters and home range and core area for jaguar in the Dry Chaco, Humid Chaco, and Paraguayan Pantanal, which furthermore take advantage of developing methods to empirically test for home range residency and account for autocorrelation in telemetry data when estimating space use (Fleming et al. 2014. 2015; Calabrese et al. 2016).

244 Our results include the largest home range estimates recorded for jaguar (Dry Chaco) and, as

245 expected, jaguars in the more productive Humid Chaco/Pantanal had smaller home ranges, lower

246 movement rates and had less directionality in movements compared to jaguars in the Dry Chaco.

247 Also, consistent with previous research males had larger home ranges, higher movement rates

248 and more directional movements than females overall and within systems. 
Overall and between systems male home ranges were larger than females which was expected (Calvalcanti and Gese 2009; Sollmann et al. 2011; Morato et al. 2016) as smaller home ranges of females are driven by food availability in relation to reproductive and offspring rearing needs which in-turn drives larger male home ranges towards optimizing reproductive opportunities (Mikael 1989; Sunquist and Sunquist 1989). This relationship is further supported

254 by our estimated movement parameters which showed that males traveled farther, faster, and more directionally than females in utilizing home ranges.

257 larger than in the Humid Chaco and Pantanal, overall and between sexes within systems where

258 male home ranges were greater than females. The larger home ranges in the Dry Chaco are

259 attributable to the lower productivity of that semi-arid ecosystem, more heterogeneously

260 distributed prey and water, and negative effects of anthropogenic factors (i.e., deforestation;

261 Fahrig 2007; Gutierrez-Gonzalez et al. 2012). The difference between sexes within systems is

262 attributable to differences in territorial organization stemming from aforementioned reproductive 263 and social needs (Mikael 1989; Sunquist and Sunquist 1989).

265 larger than other estimates from this study and Morato et al. (2016), although our estimates of 266 male home range size from the Dry Chaco (mean:925 km², 95\% CI:424-2035) are consistent

267 with the estimate for a single male from the Brazilian Cerrado (1269 $\left.\mathrm{km}^{2}\right)$, a semi-arid ecosystem

268 with environmental and land use similarities to the Gran Chaco. Morato et al. (2016)

269 demonstrated that increasing home range size of jaguars was associated with lower habitat 270 quality, which is consistent with the very large home ranges from the Dry Chaco which were 
271 closest in size to Morato et al's (2016) home ranges in the Atlantic forest which they considered

272 to be of the lowest habitat quality of their study areas.

273

We expected home range sizes from the Humid Chaco/Pantanal to be similar to estimates

274 from the Brazilian Pantanal, however, our estimates were 59\% and 112\% larger for males and

275 females, respectively than home ranges reported for the Brazilian Pantanal; falling between

276 estimates from the Amazon and Atlantic forest, although most similar to jaguars from the

277 Amazon (Morato et al. 2016; Fig. 5). These differences may be related to differences in the

278 geomorphology of the two regions and its interaction with the local hydrological cycles.

279

The Paraguayan Pantanal and our study area in the Humid Chaco have less forest area

280 and a relatively greater area of inundated land during a large portion of the year compared to the

281 Pantanal study areas of Morato et al. (2016) in Brazil. Consequently, the reduced forest area,

282 with smaller and more isolated forest patches during annual flooding, could drive the

283 comparatively larger home ranges observed in the Paraguayan Pantanal and Humid Chaco,

284 although reduced jaguar densities resulting from persecution may also play a role in liberating

285 available space and permitting greater space use.

Differences in the mean movement parameters were evident between jaguars in the

287 Humid Chaco/Pantanal and in the Brazilian Pantanal whereby movements were more directional

288 in the Humid Chaco/Pantanal, although still relatively sinuous but most similar to jaguars in the

289 Atlantic forest, while daily movements were very similar to those in the Amazon (Fig. 6).

290 Jaguars in the Dry Chaco had high movement rates and directionality in movement, similar to

291 individuals in the Amazon from seasonally flooded forests (Morato et al. 2016). 
We believe that these similarities are responses to movements among sporadically

293 distributed critical resources despite the large differences in ecosystem characteristics.

294 Conversely, although daily movement rate of jaguars in the Humid Chaco/Pantanal were similar

295 to those in the Dry Chaco and Amazon, the relatively low directionality demonstrated by jaguars

296 in the Humid Chaco/Pantanal suggests that, although jaguars are covering relatively large areas,

297 movements are in response to more homogenously distributed resources within home ranges.

Core areas, as measured by the utility distribution isopleth were highly similar across

299 systems and sexes, encompassed on average by the 59\% isopleth (95\% CI:56-64\%), which

300 represented on average 29\% (95\% CI:21-34\%) of total home range area. This indicates that

301 despite home range size, sex, or system jaguars are most intensively using about a third of their

302 home range area. Additionally, our results suggests a cautious interpretation of arbitrarily

303 defined core area delimitations, typically assigned to the 50\% utility distribution isopleths which

304 falls outside of the $95 \%$ confidence limits of our estimates (Powell 2012).

In light of the extensive deforestation that is occurring in the Dry Chaco of western

306 Paraguay, the large home ranges that we observed in this system, which are consistent with the

307 estimated low density of jaguar in the Bolivian Dry Chaco (Noss et al. 2012), are of concern as

308 they demonstrate the large forested area that jaguars in the Dry Chaco require. In the Humid

309 Chaco/Pantanal spatial requirement of jaguars were greater than expected based on estimates

310 from the Brazilian Pantanal, which suggests lower than expected densities in these systems in

311 Paraguay and cautions against extrapolating population parameter estimates from other regions

312 within the Pantanal to the Rio Paraguay flood plain in Paraguay. 
In both the Dry Chaco and the Humid Chaco/Pantanal we recognize that there may be an important effect on space use caused by reduced jaguar densities from persecution which is pervasive throughout western Paraguay, illustrated by our confirmation, or high probability, of

$316 \sim 75 \%$ of our study animals being killed due to persecution. Persecution is common throughout

317 the range of the jaguar, however, its practice and magnitude is not equivocal geographically and

318 consequently how the removal of individuals may impact space use, and subsequently

319 comparisons among ecosystems and regions, needs to be considered and is of interest for future 320 research.

The large spatial requirements of jaguars in western Paraguay, particularly in the Dry

322 Chaco, indicate that the protected areas of the region which, represent $<5 \%$ of the total regional

323 area are likely insufficient to maintain a viable regional population, especially in light of the

324 level of persecution on private lands. This highlights an urgent need to mitigate jaguar-human

325 conflict in the region by actively including the livestock production sector in the conservation

326 decision making process. Furthermore, given continuing deforestation, conservation initiatives

327 need to take into account the large spatial needs of jaguar in western Paraguay by recognizing

328 and incorporating the role of private lands in the long-term conservation of the species in

329 Paraguay and in maintaining trans-boundary connectivity among populations.

\section{Acknowledgements}

332 We thank DVM Sybil Zavala, Cougar McBride and Caleb McBride for assistance in the field 333 and the many sportsman and conservationist who contributed to supporting this work. This

334 research was conducted under the permission of the Secretariat of the Environment (SEAM) of 
335 Paraguay. JJT was supported by the Consejo Nacional de Ciencia y Tecnología of Paraguay

336 (CONACYT).

\section{References}

Azevedo, F. C. C. and D. L.,Murray. 2007. Spatial organization and food habits of jaguars

(Panthera onca) in a floodplain forest. Biol. Conserv. 137:391-401.

Bingham, B.B. and B.R. Noon. 1997. Mitigation of habitat "take": Application to habitat conservation planning. Conserv Biol. 11:127-139.

Brodie, J.F. 2009. Is research effort allocated efficiently for conservation? Felidae as a global case study. Biodivers Conserv. 18:2927-2939. relocation data as a continuous-time stochastic process. Methods Ecol Evol. 7:1124-1132.

347 Calenge, C. 2006. The package adehabitat for the R software: a tool for the analysis of space and 348 habitat use by animals. Ecol Model. 197:516-519.

349 Cardillo, M., A. Purvis, W. Sechrest, J.L. Gittleman, J. Bielby and G.M. Mace. 2004. Human population density and extinction risk in the world's carnivores. PLOS Biology 2(7): e197. doi:

351 10.1371/journal.pbio.0020197.

352 Caso, A., C. Lopez-Gonzalez,, E. Payan, E. Eizirik, T. de Oliveira, R. Leite-Pitman, M. Kelly

353 and C. Valderrama, 2008. Panthera onca. The IUCN Red List of Threatened Species 2008: 

differences for jaguar conservation. Biol Conserv. 143, 1980-1988. onca) in a protected subtropical forest in Brazil and Argentina. Ph.D. dissertation, University of Florida. Gainsville, Florida, USA. seasonally flooded environment in Brazil. J. Zool. 223, 357-370. Silvius. 2004. Ecology and conservation of the jaguar (Panthera onca) in Iguaçu National Park, conservation in South and Central America. Columbia University Press, New York. pp. 286296.

373 Crooks, K.R., 2002. Relative sensitivities of mammalian carnivores to habitat fragmentation.

374 Conserv Biol. 16, 488-502.

375 Cullen Jr., L., 2006. Jaguar as landscape detectives for the conservation in the Atlantic Forest of 376 Brazil. Ph.D. dissertation. University of Kent, UK.

377 de la Torre, J.A., J.F. González-Maya, H. Zarza, G. Ceballos and R.A. Medellín, 2017. The 378 jaguar's spots are darker than they appear: assessing the global conservation status of the jaguar 379 Panthera onca. Oryx.1-16. doi:10.1017/S0030605316001046 
Fahrig, L., 2007. Non-optimal animal movement in human-altered landscapes. Funct Ecol. 21, 1003-1015.

Fleming, C.H., J.M. Calabrese, T. Mueller, K.A. Olson, P. Leimgruber and W.F. Fagan. 2014.

From fine-scale foragingto home ranges: a semivariance approach to identifying movement modes across spatiotemporal scales. Am Nat. 183: E154-E167.

Fleming, C.H., W.F. Fagan, T. Mueller, K.A. Olson, P, Leimgruber and J.M. Calabrese. 2015. estimator. Ecology. 96, 1182-1188.

Gutiérrez-González, C.E., M.Á. Gómez-Ramírez and C.A. López-González. 2012. Estimation of and an open population model. Oryx, 46, 431-437.

395 framework: concepts, structure, and extensibility. Stat Comput, 10, 325-337.

396 McBride, Jr., R.T. and R.T. McBride. 2007. Safe and selective capture technique for jaguars in 397 the Paraguayan Chaco. Southwest Nat. 52, 570-577.

398 Macdonald, D.W. 1983. The ecology of carnivore social behaviour. Nature. 301, 379-384.

399 Mereles, F., J.L. Cartes, R.P. Clay, P. Cacciali, C. Paradeda, O. Rodas and A. Yanosky, 2013.

400 Análisis cualitativo para la definición de las ecorregiones de Paraguay occidental. Paraquaria

$401 \quad$ Natural. 1, 12-20. 
402

403

404

405

406

407

408

409

410

411

412

413

414

415

416

417

418

419

420

421

422

423

Mikael, S. 1989. The mating tactics and spacing patterns of solitary carnivores, In: (Gittleman, J.L.,ed.). Carnivore behavior, ecology, and evolution. Cornell University Press, New York. pp. $164-182$.

Morato, R.G., J.A. Stabach, C.H. Fleming, J.M. Calabrese, R.C. De Paula, K.M. Ferraz, D.L. Kantek, S.S. Miyazaki, T.D. Pereira, G.R. Araujo, A. Paviolo, C. De Angelo, M.S. Di Bitetti, P. Cruz, F. Lima, L. Cullen, D.A. Sana, E.E. Ramalho, M.M. Carvalho, F.H.S. Soares, B. Zimbres, M.X. Silva, M.D.F. Moraes, A. Vogliotti, J.A. May, Jr., M. Haberfeld, L. Rampim, L. Sartorello, M.C. Ribeiro and P. Leimgruber. 2016. Space Use and Movement of a Neotropical Top

Predator: The Endangered Jaguar. PloS one, 11(12), p.e0168176.

Noss, A.J., B. Gardner, L. Maffei, E. Cuéllar, R. Montaño, A. Romero $\square$ Muñoz, R. Sollman and A.F. O'Connell. 2012. Comparison of density estimation methods for mammal populations with camera traps in the Kaa $\square$ Iya del Gran Chaco landscape. Anim Conserv. 15, 527-535.

Olson, D.M., E. Dinerstein, E.D. Wikramanayake, N.D. Burgess, G.V. Powell, E.C. Underwood, J.A. D'amico, I. Itoua, H.E. Strand,J.C. Morrison and C.J. Loucks. 2001. Terrestrial Ecoregions of the World: A New Map of Life on Earth: A new global map of terrestrial ecoregions provides an innovative tool for conserving biodiversity. BioScience, 51, 933-938.

Petracca, L.S., S. Hernández-Potosme, L. Obando-Sampson, R. Salom-Pérez, H. Quigley and H.S. Robinson. 2014a. Agricultural encroachment and lack of enforcement threaten connectivity of range-wide jaguar (Panthera onca) corridor. J Nat Conserv. 22, 436-444.

Petracca, L.S., O.E. Ramírez-Bravo and L.Hernández-Santín. 2014b. Occupancy estimation of jaguar Panthera onca to assess the value of east-central Mexico as a jaguar corridor. Oryx, 48, 133-140. 
424 Powell, R.A. 2012. Movements, home ranges, activity, and dispersal, In: (Boitani, L. and R.A.

425 Powell, eds.), Carnivore ecology and conservation: a handbook of techniques. Oxford University

426 Press, London, United Kingdom. pp. 188-217.

427

428 R Development Core Team, 2010. R:A language and environment for statistical computing. R

429 Foundation for Statistical Computing, Vienna, Austria.

430 Rabinowitz, A.R. and B.G. Nottingham. 1986. Ecology and behavior of the jaguar (Panthera

431 onca) in Belize, Central America. J Zool. 210, 149-159.

432 Rabinowitz, A. and K.A. Zeller. 2010. A range-wide model of landscape connectivity and

433 conservation for the jaguar, Panthera onca. Biol. Conserv. 143, 939-945.

434 Ripple, W.J., J.A. Estes, R.L. Beschta, C.C. Wilmers, E.G., Ritchie, M. Hebblewhite, J. Berger,

435 B. Elmhagen, M. Letnic, M.P. Nelson and O.J. Schmitz. 2014. Status and ecological effects of

436 the world's largest carnivores. Science. 343(6167), 1241484.

437 Sanderson, E.W., K.H. Redford, C.B. Chetkiewicz, R.A. Medellin, A.R. Rabinowitz, , J.G.

438 Robinson and A.B. Taber. 2002. Planning to save a species: the jaguar as a model. Conserv.

439 Biol. 16, 58-71.

440 Schaller, G.B. and P.G. Crawshaw, Jr. 1980. Movement patterns of jaguar. Biotropica 12, 161-

441168.

442 Secretaría del Ambiente, Wildlife Conservation Society Paraguay and Itaipu Binacional, 2016.

443 Plan de Manejo de la Panthera onca, Paraguay 2017-2026. First ed., Asunción, Paraguay.

444 Seaman, D.E. and R.A. Powell. 1990. Identifying patterns and intensity of home range use.

445 Bears: their biology and management Vol. 8, A Selection of Papers from the Eighth International

446 Conference on Bear Research and Management. Victoria, British Columbia, Canada, February

447 1989. International Association of Bear Research and Management. pp.243-249. 
448 Scognamillo, D., I. Maxit, M. Sunquist and L. Farrell. 2002. Ecología del jaguar y el problema

449 de la depredación de ganado en un hato de los llanos venezolanos. In: (Medellin, R., C. Equihua,

450 C.L.B. Chetkiewicz, P.G. Crawshaw, Jr., A. Rabinowitz, K.H. Redford, J.G. Robinson, E.W.

451 Sanderson and A.B. Taber, eds.), El jaguar en el nuevo milenio. Universidad Nacional

452 Autónoma de México and Wildlife Conservation Society, Distrito Federal, México. pp. 139-150

453 Sikes, R.S. 2016. Guidelines of the American Society of Mammalogists for the use of wild

454 mammals in research and education. J Mammal. 97, 663-688.

455 Silveira, L. 2004. Ecologia Comparada e Conservação da Onça-pintada (Panthera onca) e Onça-

456 parda (Puma concolor), no Cerrado e Pantanal. Ph.D. Dissertation, University of Brasilia,

457 Brasilia, Brasil.

458 Sollmann, R., M.M. Furtado, B. Gardner, H. Hofer, A.T. Jácomo, , N.M. Tôrres, and L.

459 Silveira. 2011. Improving density estimates for elusive carnivores: accounting for sex-specific

460 detection and movements using spatial capture-recapture models for jaguars in central Brazil.

461 Biol Conserv., 144, 1017-1024.

462 Sturtz, S., U. Ligges and A. Gelman. 2005. R2WinBUGS: A Package for Running WinBUGS

463 from R. J Stat Soft., 12, 1-16.

464 Sunquist, M.E. and F.C. Sunquist.1989. Ecological constraints on predation by large felids. In:

465 (Gittleman, J.L., ed.), Carnivore behavior, ecology, and evolution. Cornell University Press,

466 Ithaca, New York. pp. 283-301

467 Thompson, J.J. and C. Martínez Martí. 2015. Patterns and determinants of jaguar (Panthera

468 onca) occurence in habitat corridors at the southwestern extent of the species range. In:

469 (Martínez Martí, C., ed.), Cats, Cores and Corridors: A survey to assess the status of Jaguars and 470 their habitat in the southernmost part of their range. Panthera. New York. pp. 26-40. 
471 Tobler, M.W., S.E. Carrillo-Percastegui, A.Z. Hartley, and G.V. Powell, 2013. High jaguar

472 densities and large population sizes in the core habitat of the southwestern Amazon. Biol

473 Conserv, 159, 375-381.

474 Vander Wal, E. and A.R. Rodgers. 2012. An individual-based quantitative approach for

475 delineating core areas of animal space use. Ecol Model. 224, 48-53.

476 Zeller, K.A. 2007. Jaguars in the New Millennium Data Set Update: The State of the

477 Jaguar in 2006. Wildlife Conservation Society, Bronx, New York.

478 Zeller, K.A., S. Nijhawan, R. Salom-Pérez, S.H. Potosme, and J.E. Hines. 2011. Integrating

479 occupancy modeling and interview data for corridor identification: a case study for jaguars in

480 Nicaragua. Biol Conserv. 144, 892-901.

481

482

483

484

485

486

487 
489 Table 1. Sex, age, sample characteristics and estimated movement parameters, AKDE home

490 range, core area and core area utility distribution isopleths for study jaguars in the Paraguayan

491 Dry Chaco, Humid Chaco and Pantanal.

\begin{tabular}{|c|c|c|c|c|c|c|c|c|}
\hline ID & $\begin{array}{l}\text { Sex/age } \\
(y r)\end{array}$ & $\begin{array}{l}\text { Number } \\
\text { of } \\
\text { fixes/days }\end{array}$ & $\begin{array}{l}\text { Velocity } \\
\text { autocorre } \\
\text { lation } \\
\text { timescale } \\
\text { (h) }\end{array}$ & $\begin{array}{l}\text { Home } \\
\text { range } \\
\text { crossing } \\
\text { time } \\
\text { (days) }\end{array}$ & $\begin{array}{l}\text { Average } \\
\text { distance } \\
\text { traveled } \\
\text { (km/day) }\end{array}$ & $\begin{array}{l}\text { Home range }\left(\mathrm{km}^{2}\right) \\
(95 \% \mathrm{CI})\end{array}$ & $\begin{array}{l}\text { Core } \\
\left(\mathrm{km}^{2}\right)\end{array}$ & $\begin{array}{l}\text { Core area } \\
\text { isopleths } \\
(\%)\end{array}$ \\
\hline \multicolumn{9}{|c|}{ Dry Chaco } \\
\hline DC1 & $\mathrm{M} / 5$ & $1094 / 376$ & 1.1 & 8.0 & 28.8 & $2143(1558-2820)$ & 504 & 59 \\
\hline DC3 & $\mathrm{M} / 2$ & $722 / 363$ & 1.8 & 11.5 & 7.9 & $421(288-580)$ & 107 & 63 \\
\hline DC4 & $\mathrm{M} / 5$ & $620 / 82$ & 1.9 & 3.5 & 15.0 & $550(349-797)$ & 182 & 58 \\
\hline DC6 & $\mathrm{M} / 7$ & $1387 / 393$ & 2.2 & 4.8 & 19.3 & $1063(822-1335)$ & 329 & 57 \\
\hline DC7 & $\mathrm{M} / 5$ & $3462 / 439$ & 1.4 & 2.7 & 17.1 & $445(381-515)$ & 85 & 64 \\
\hline DC5 & $\mathrm{F} / 6$ & $1610 / 386$ & 1.1 & 11.5 & 11.8 & $591(411-805)$ & 178 & 59 \\
\hline$\overline{\mathrm{DC} 2}$ & $\mathrm{~F} / 8$ & $921 / 379$ & 1.7 & 9.5 & 9.7 & $511(363-683)$ & 176 & 56 \\
\hline \multicolumn{9}{|c|}{ Humid Chaco/Pantanal } \\
\hline Pan2 & $\mathrm{F} / 2$ & $1694 / 375$ & 1.1 & 4.3 & 7.9 & $71(58-85)$ & 24 & 60 \\
\hline HC5 & $\mathrm{F} / 4$ & $593 / 242$ & 0.5 & 1.2 & 20.9 & $92(75-110)$ & 23 & 61 \\
\hline $\mathrm{HC} 4$ & $F / 3$ & $288 / 266$ & 1.5 & 6.2 & 9.3 & $270(187-369)$ & 86 & 57 \\
\hline $\mathrm{HC} 8$ & $\mathrm{~F} / 1$ & $980 / 170$ & 0.2 & 10.2 & 13.7 & $121(71-183)$ & 32 & 58 \\
\hline $\mathrm{HC} 7$ & $\mathrm{~F} / 6$ & $1668 / 324$ & 0.1 & 9.2 & 22.3 & $246(172-332)$ & 73 & 57 \\
\hline
\end{tabular}


bioRxiv preprint doi: https://doi.org/10.1101/119412; this version posted May 14, 2017. The copyright holder for this preprint (which was not certified by peer review) is the author/funder, who has granted bioRxiv a license to display the preprint in perpetuity. It is made available under aCC-BY-NC-ND 4.0 International license.

\begin{tabular}{|r|r|r|r|r|r|r|r|r|}
\hline HC9 & F/6 & $928 / 362$ & 0.2 & 9.7 & 13.9 & $118(83-159)$ & 33 & 59 \\
\hline Pan3 & M/6 & $727 / 192$ & 1.4 & 3.4 & 16.6 & $428(320-550)$ & 134 & 57 \\
\hline HC3 & M/4 & $983 / 143$ & 1.4 & 4.4 & 15.0 & $424(290-584)$ & 138 & 56 \\
\hline HC6 & M/10 & $660 / 133$ & 0.9 & 5.5 & 13.4 & $341(216-494)$ & 91 & 60 \\
\hline Pan1 & F/4 & $1695 / 366$ & NA & 3.5 & NA & $550(349-797)$ & 21 & 60 \\
\hline HC1 & M/6 & $148 / 88$ & NA & 5.9 & NA & $958(534-1505)$ & 283 & 58 \\
\hline HC2 & F/6 & $280 / 54$ & NA & 5.7 & NA & $73(35-125)$ & 22 & 57 \\
\hline
\end{tabular}

492

493

494

495

496

497

498

499

500

501

502 
Table 2. Probabilites, based upon posterior distributions, that home range and movement parameters are different between sex and ecosystem, between sexes within systems, and between

505 same sexes between systems.

\begin{tabular}{|c|c|c|c|c|}
\hline & $\begin{array}{l}\text { Home range } \\
\left(\mathrm{km}^{2}\right)\end{array}$ & $\begin{array}{l}\text { Home range } \\
\text { crossing time } \\
\text { (days) }\end{array}$ & $\begin{array}{l}\text { Velocity } \\
\text { autocorrelation } \\
\text { timescale (h) }\end{array}$ & $\begin{array}{l}\text { Average distance } \\
\text { traveled } \\
\text { (km/day) }\end{array}$ \\
\hline $\begin{array}{l}\text { Dry Chaco male }>\text { Dry } \\
\text { Chaco female }\end{array}$ & 0.71 & 0.08 & 0.71 & 0.89 \\
\hline $\begin{array}{l}\text { Humid } \\
\text { Chaco/Pantanal male > } \\
\text { Humid } \\
\text { Chaco/Pantanal female }\end{array}$ & 0.99 & 0.17 & 0.95 & 0.52 \\
\hline $\begin{array}{l}\text { Dry Chaco male > } \\
\text { Humid } \\
\text { Chaco/Pantanal male }\end{array}$ & 0.91 & 0.75 & 0.86 & 0.72 \\
\hline $\begin{array}{l}\text { Dry Chaco female > } \\
\text { Humid } \\
\text { Chaco/Pantanal female }\end{array}$ & 0.99 & 0.89 & 0.96 & 0.23 \\
\hline $\begin{array}{l}\text { All Dry Chaco > All } \\
\text { Humid } \\
\text { Chaco/Pantanal }\end{array}$ & 1 & 0.77 & 0.99 & 0.61 \\
\hline Male $>$ Female & 0.99 & 0.10 & 0.99 & 0.84 \\
\hline
\end{tabular}




\section{7 \\ Supplementary material}

508

Table A.1. Comparative home range sizes for study jaguars based upon autocorrelated kernel

509 density estimator (AKDE), 95\% kernel density estimator (KDE), and 95\% minimum convex

510 polygon (MCP).

\begin{tabular}{|c|c|c|c|c|}
\hline ID & Sex/age (yr) & $\begin{array}{l}\text { AKDE Home range }\left(\mathrm{km}^{2}\right) \\
(95 \% \mathrm{CI})\end{array}$ & $95 \% \operatorname{KDE}\left(\mathrm{km}^{2}\right)$ & $95 \% \operatorname{MCP}\left(\mathrm{km}^{2}\right)$ \\
\hline \multicolumn{5}{|c|}{ Dry Chaco } \\
\hline DC1 & $\mathrm{M} / 5$ & $2143(1558-2820)$ & 1674 & 1813 \\
\hline DC3 & $\mathrm{M} / 2$ & $421(288-580)$ & 193 & 152 \\
\hline DC4 & $\mathrm{M} / 5$ & $550(349-797)$ & 453 & 389 \\
\hline DC6 & $\mathrm{M} / 7$ & $1063(822-1335)$ & 877 & 950 \\
\hline DC7 & $\mathrm{M} / 5$ & $445(381-515)$ & 418 & 587 \\
\hline DC5 & $\mathrm{F} / 6$ & $591(411-805)$ & 479 & 475 \\
\hline DC2 & $\mathrm{F} / 8$ & $511(363-683)$ & 402 & 298 \\
\hline \multicolumn{5}{|c|}{ Humid Chaco/Pantanal } \\
\hline Pan2 & $\mathrm{F} / 2$ & $71(58-85)$ & 71 & 87 \\
\hline HC5 & $\mathrm{F} / 4$ & $92(75-110)$ & 102 & 89 \\
\hline $\mathrm{HC} 4$ & $\mathrm{~F} / 3$ & $270(187-369)$ & 176 & 151 \\
\hline $\mathrm{HC} 7$ & $F / 1$ & $121(71-183)$ & 87 & 88 \\
\hline $\mathrm{HC} 8$ & $\mathrm{~F} / 6$ & $246(172-332)$ & 205 & 184 \\
\hline HC9 & $\mathrm{F} / 6$ & $118(83-159)$ & 87 & 96 \\
\hline Pan3 & $\mathrm{M} / 6$ & $428(320-550)$ & 350 & 288 \\
\hline
\end{tabular}


bioRxiv preprint doi: https://doi.org/10.1101/119412; this version posted May 14, 2017. The copyright holder for this preprint (which was not certified by peer review) is the author/funder, who has granted bioRxiv a license to display the preprint in perpetuity. It is made available under aCC-BY-NC-ND 4.0 International license.

\begin{tabular}{|r|r|r|r|r|}
\hline HC2 & M/4 & $424(290-584)$ & 302 & 255 \\
\hline HC6 & M/10 & $341(216-494)$ & 280 & 256 \\
\hline Pan1 & F/4 & $550(349-797)$ & 59 & 491 \\
\hline HC1 & M/6 & $958(534-1505)$ & 644 & 36 \\
\hline HC3 & F/6 & $73(35-125)$ & 52 & \\
\hline
\end{tabular}

511

512

513

514

515

516

517

518

519

520

521

522

523 
524 Figure 1. Map showing the distribution of the Dry and Humid Chaco and Pantanal in western

525 Paraguay (Olson et al. 2001) and study areas where jaguar movements were monitored.

526 Figure 2. Home range and movement parameters of male and female jaguars across all study

527 sites.

528 Figure 3. Home range and movement parameters for study jaguars in the Dry Chaco and Humid

529 Chaco/Pantanal.

530 Figure 4. Home range and movement parameters of male and female jaguars in the Dry Chaco

531 and Humid Chaco/Pantanal.

532 Figure 5. Mean male and female home ranges (error bars represent 95\% confidence interval)

533 from this study and AKDE estimates from Morato et al. (2016) by ecosystem. The numbers next

534 to points represent sample size.

535 Figure 6. Mean of the mean distance traveled and the velocity autocorrelation timescale (error

536 bars represent SE) of jaguars from this study and mean estimates from Morato et al. (2016) by

537 ecosystem. 


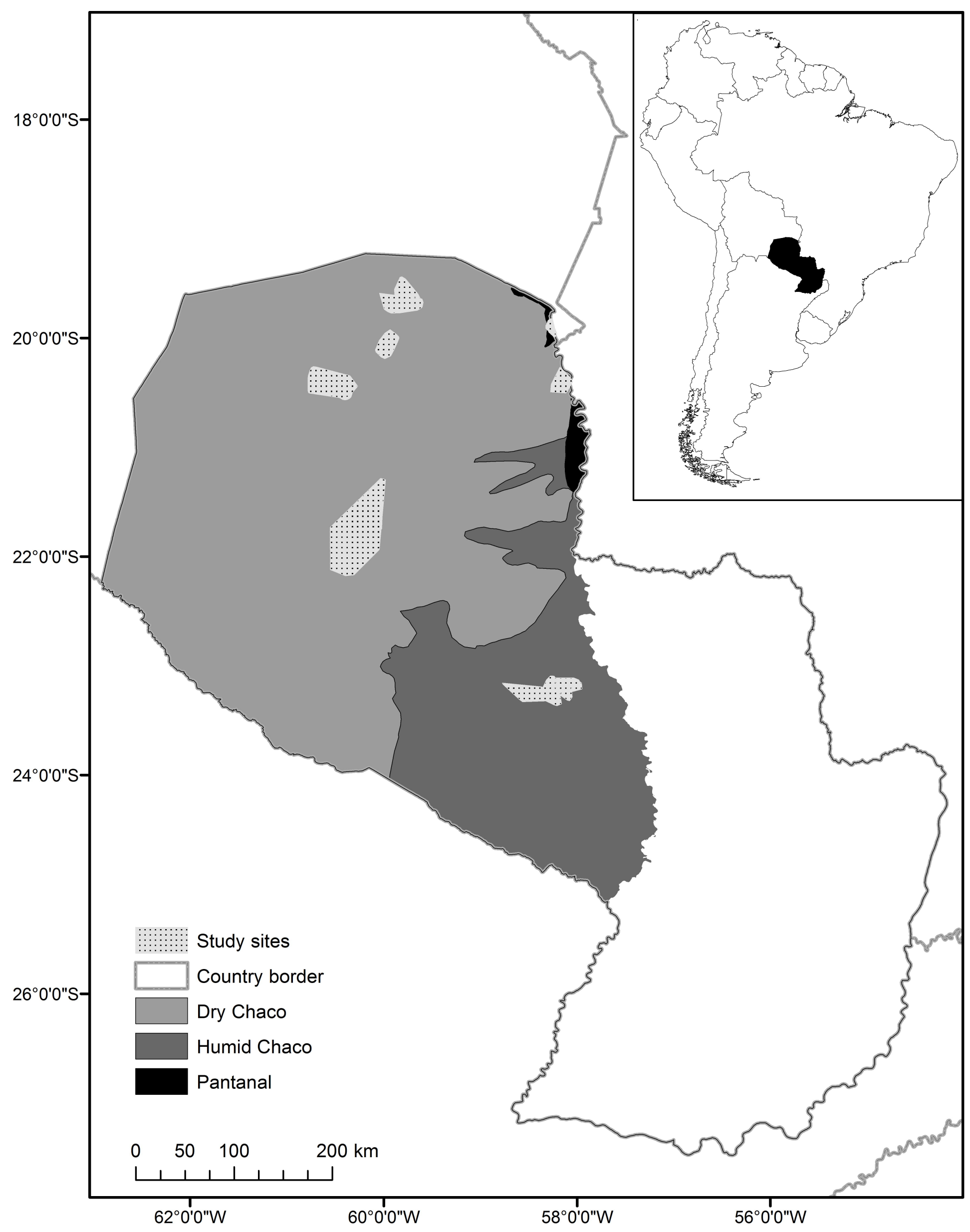



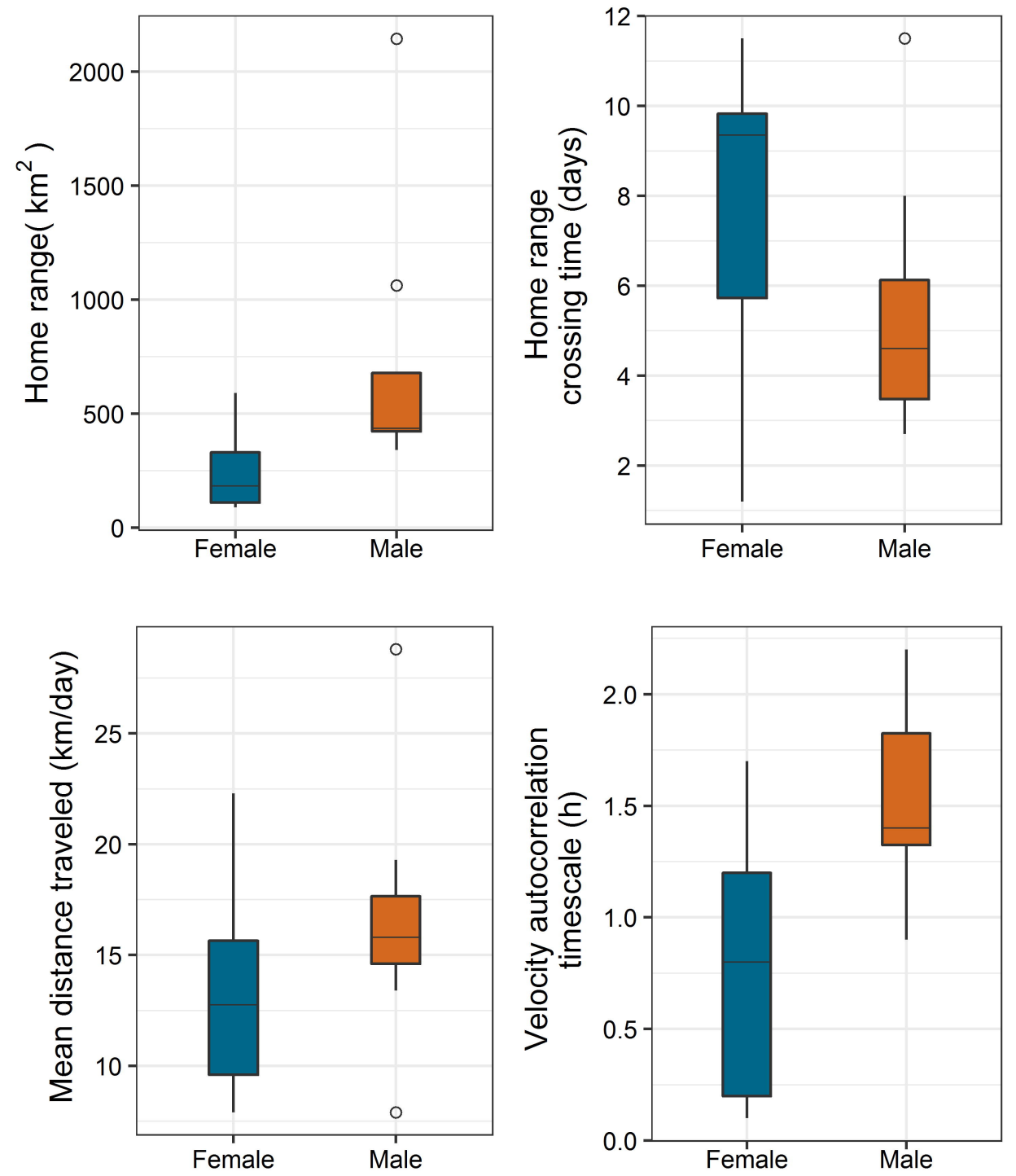


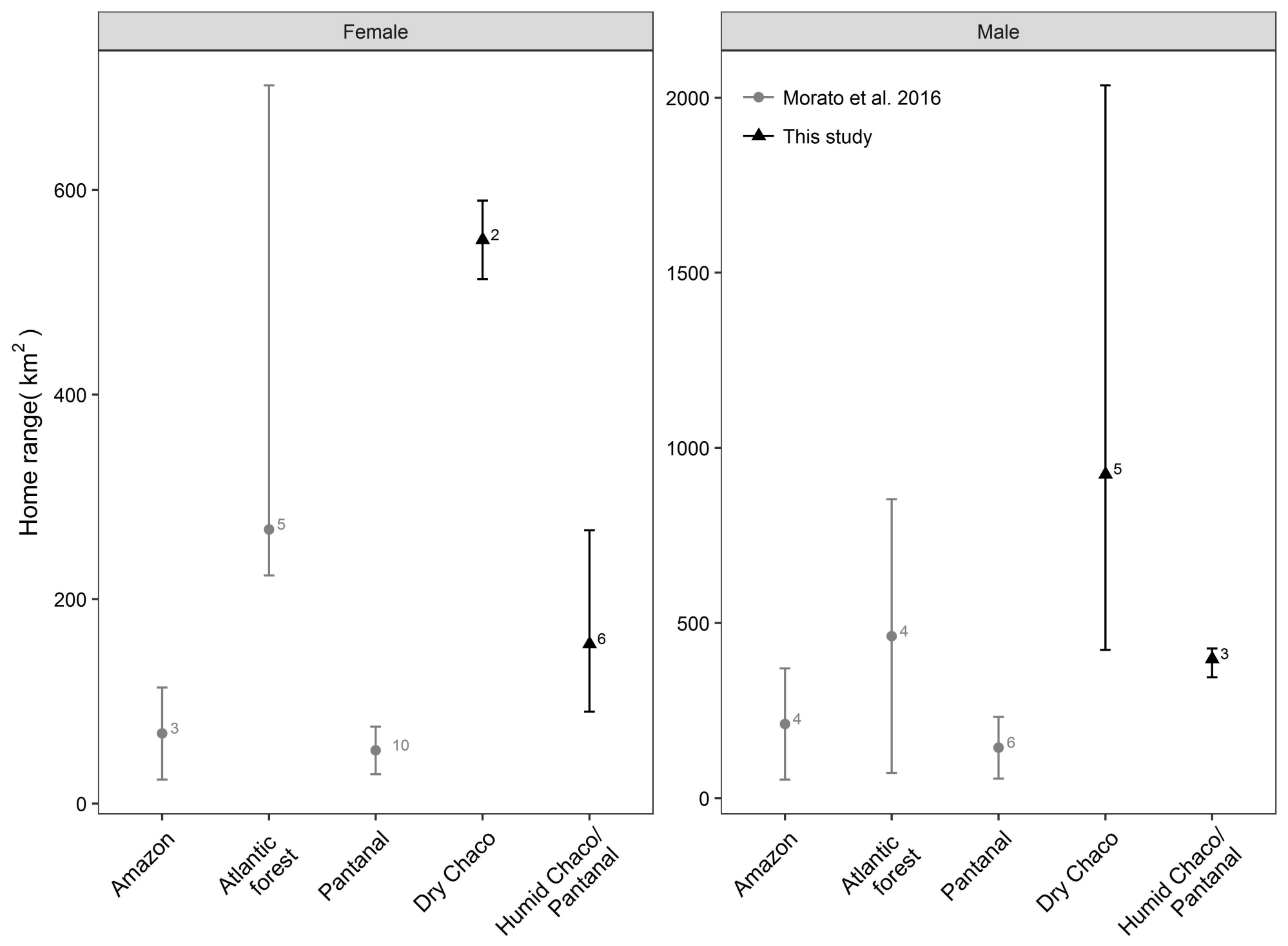




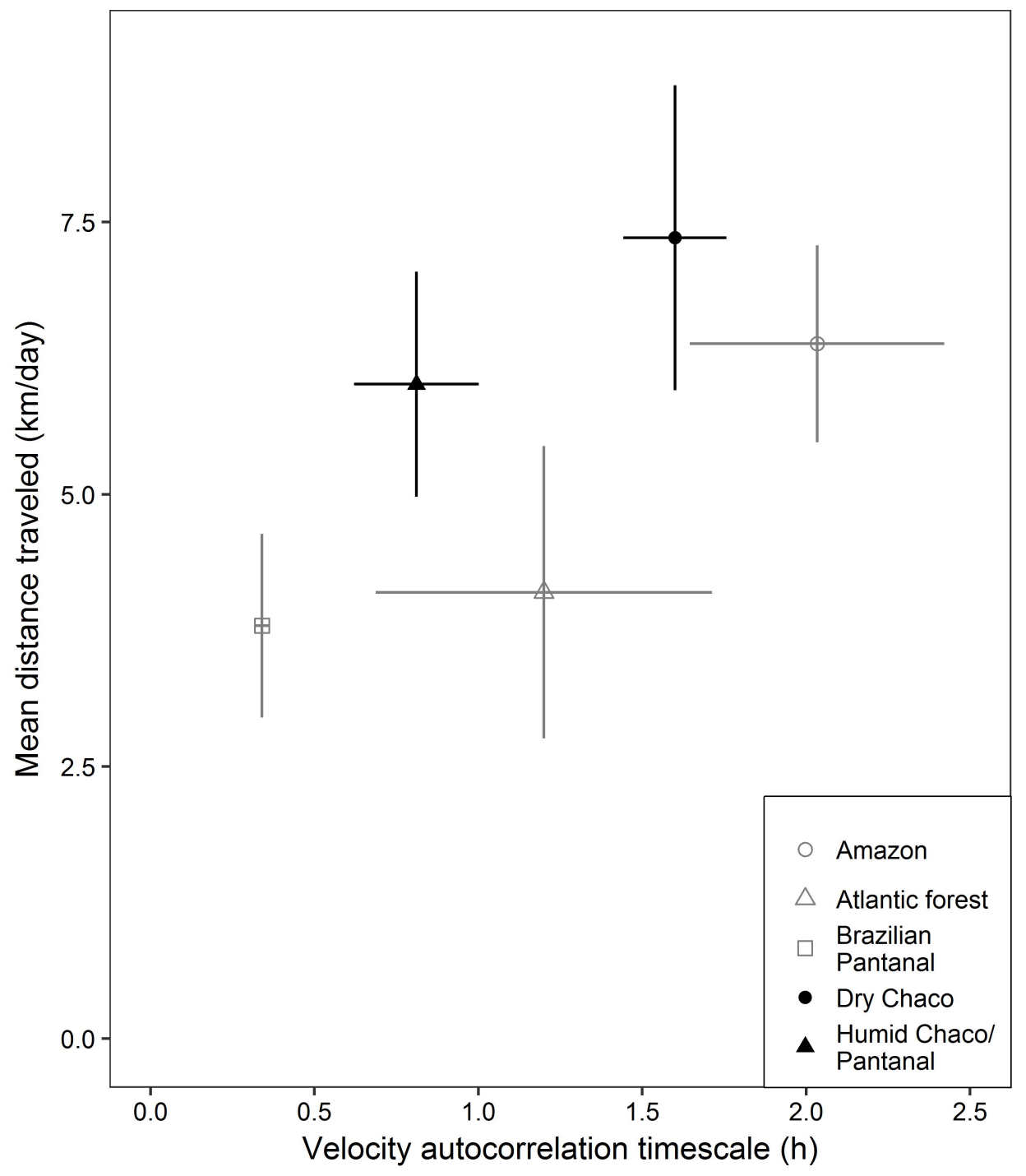

